\title{
Biological indicators of the timing and direction of warm-water advection during the 1997/1998 El Niño off the central Oregon coast, USA
}

\author{
Julie E. Keister ${ }^{1, *}$, Travis B. Johnson ${ }^{2}$, Cheryl A. Morgan ${ }^{3}$, William T. Peterson ${ }^{4}$ \\ ${ }^{1}$ Oregon State University, College of Oceanic and Atmospheric Sciences, 104 COAS Administration Building, Corvallis, \\ Oregon 97331-5503, USA \\ ${ }^{2}$ Ocean Research Institute, The University of Tokyo, Center for International Cooperation, 1-51-1 Minamidai, Nakano-ku, \\ Tokyo 164-8639, Japan \\ ${ }^{3}$ Oregon State University, Cooperative Institute for Marine Resources Studies, 2030 S. Marine Science Drive, Newport, \\ Oregon 97365, USA \\ ${ }^{4}$ NOAA Fisheries, Hatfield Marine Science Center, 2030 S. Marine Science Drive, Newport, Oregon 97365, USA
}

\begin{abstract}
Unusual collections of several euphausiid, chaetognath, and copepod species help elucidate the effects of the strong 1997/1998 El Niño off the central Oregon, USA, coast. Furcilia of Nyctiphanes simplex, a euphausiid typically found only as far north as central California, were collected in bi-weekly nearshore samples between December 1997 and November 1998. N. simplex was reported in summer 1998 as far north as the northern tip of Vancouver Island, British Columbia, Canada $\left(51^{\circ} \mathrm{N}\right)$; our bi-weekly collections off Oregon allow us to use that species to help resolve the timing of arrival and disappearance of the biological signal of the El Niño, which was delayed by several months beyond the physical signal. Additionally, 2 species of euphausiid (Euphausia recurva and E. mutica), 2 species of chaetognath (Sagitta pseudoserratodentata and S. hexaptera), and 1 copepod (Centropages bradyi) that have never before been reported in coastal Oregon waters were collected in samples taken between 28 and $103 \mathrm{~km}$ off Oregon during the 1997/1998 El Niño. The 1997/1998 El Niño was one of the strongest on record and the occurrence of the unusual species may indicate the extent of the northward and onshore advection of warm water into the study area.
\end{abstract}

KEY WORDS: Nyctiphanes simplex · El Niño · Euphausids · Sagitta spp. · Range extension · Advection · Oregon · Zooplankton

Resale or republication not permitted without written consent of the publisher

\section{INTRODUCTION}

The 1997/1998 El Niño was one of the strongest El Niños on record (McPhaden 1999). Off central Oregon, USA, anomalously warm water was noted as early as May 1997 (Peterson et al. 2002). The first definitive sign of the arrival of an oceanic El Niño signal was observed in late August, when the sea level rose by several centimeters (Strub \& James 2002). Water of 1 to $2^{\circ} \mathrm{C}$ above normal at depths of several hundred meters and anomalously strong poleward flows were noted off Oregon in September 1997 (Huyer et al. 2002). Warm sea surface temperatures $\left(>2^{\circ} \mathrm{C}\right.$ above average) persisted through April 1998; in deep water, warm temperatures persisted through September 1998 (Huyer et al. 2002).
The effects of El Niño events reach mid-latitude regions of the west coast of North America by 2 avenues: through the atmosphere and through the ocean. The atmospheric teleconnection modifies winds, storm tracks, and temperatures; the oceanic connection is through Kelvin waves, which result in a strong poleward flow of water over the continental shelf. Poleward surface flows off central Oregon averaged $13.7 \mathrm{~cm} \mathrm{~s}^{-1}$ higher than normal during August 1997 to February 1998 (Kosro 2002). The flow anomalies could possibly have resulted in anomalous northward transport of plankton and fish by as much as $350 \mathrm{~km} \mathrm{mo}^{-1}$, which corresponds to about $3.2^{\circ}$ of latitude $\mathrm{mo}^{-1}$. If these rates represent coast-wide averages, then over the August to February period, 
anomalous poleward transport of $>20^{\circ}$ latitude was possible.

It is well known that organisms can be found well poleward of their usual range during strong El Niño events, some because they are transported by anomalously poleward geostrophic currents, and some because normally cool areas warm and become habitable. For example, Pearcy (2002) reported on the occurrences of several warm-water species of fish and squid off Oregon during the 1997/1998 El Niño, including the jumbo squid Dosidicus gigas D'orbigny, 1835, which had never before been reported off Oregon. Pearcy et al. (1985) reported occurrences of 4 species of fish during the 1982/1983 El Niño never previously collected north of California. Rojas (2001), who worked between Punta Baja and Punta Abreojos, Baja California, Mexico, in October 1997 and 1999, found species associated with tropical and equatorial waters during the 1997/1998 El Niño which were brought there with northward flow of subtropical waters.

Nyctiphanes simplex Hansen, 1911, is a dominant and ecologically important euphausiid in upwelling areas off Baja California (Lavaniegos 1995). It is a neritic species whose normal range extends from Baja into southern California $\left(\sim 34^{\circ} \mathrm{N}\right)$ (Brinton \& Townsend 1980, 2003). During the 1982/1983 El Niño, Brodeur (1986) collected N. simplex as far north as Seaside, Oregon $\left(46^{\circ} \mathrm{N}\right)$ and found specimens of $N$. simplex in stomachs of fish caught off Cape Flattery, Washington $\left(48^{\circ} 20^{\prime} N\right)$. Slightly north of $N$. simplex's usual northern boundary, Marinovic et al. (2002) collected N. simplex in Monterey Bay $\left(36.5^{\circ} \mathrm{N}\right)$ between July 1997 and November 1998. Tanasichuk \& Cooper (2002) and Mackas \& Galbraith (2002) reported finding N. simplex off Vancouver Island, British Columbia, Canada (48 to $51^{\circ} \mathrm{N}$ ) during summer 1998.

Here we report on the occurrence of Nyctiphanes simplex in Oregon waters during the 1997/1998 El Niño and provide evidence on the timing of arrival and disappearance of $N$. simplex based on our continuous time-series of samplings conducted since 1996. Additionally, we report on the occurrence of 2 other euphausiid species, 2 chaetognaths, and 1 copepod species that had never before been recorded in nearshore waters off Oregon. The normal ranges of these species help resolve the direction of transport of the warm water that occurred off Oregon during the 1997/1998 El Niño.

\section{MATERIALS AND METHODS}

Two research programs contribute to the findings reported here. Euphausiid and chaetognath data are from surveys collected as part of the US GLOBEC (Global Ocean Ecosystem Dynamics) Northeast Pacific program. Since 1996, zooplankton have been collected approximately bi-weekly off Newport, Oregon (44 ${ }^{\circ}$ $40^{\prime} \mathrm{N}$ ) (Fig. 1) at stations 9 (Stn NH5, $60 \mathrm{~m}$ water depth) and 28 (Stn NH15, $90 \mathrm{~m}$ water depth) $\mathrm{km}$ from shore with a $1 / 2 \mathrm{~m}$ diameter, $202 \mu \mathrm{m}$ mesh net hauled vertically from near-bottom at $30 \mathrm{~m} \mathrm{~min}^{-1}$. Also as part of US GLOBEC, beginning in January 1998, stations along the same transect were sampled 5 times $\mathrm{yr}^{-1}$ up to $120 \mathrm{~km}$ from shore with a $1 \mathrm{~m}$ diameter, $335 \mu \mathrm{m}$ mesh net towed obliquely at 2 knots from $20 \mathrm{~m}$ depth to surface. Stns NH10 (18 km from shore, $80 \mathrm{~m}$ depth) and NH25 (46 km offshore, $290 \mathrm{~m}$ depth) were included in those surveys (Fig. 1). All nets were fitted with flowmeters. Samples were preserved in 5\% buffered formalin. Many of the $1 \mathrm{~m}$ net samples have not been sorted, so most of the results reported here are from the vertical net collections.

Copepod data come from a survey conducted in July 1997 by the Estuarine and Ocean Ecology Team of the National Marine Fisheries Service. Latitudinal transects extended from 2 to up to $185 \mathrm{~km}$ offshore and ranged from the Columbia River $\left(46^{\circ} 16.2^{\prime} \mathrm{N}\right)$ to just south of Cape Blanco $\left(42^{\circ} 37.2^{\prime} \mathrm{N}\right)$ (Fig. 1). Vertical tows were conducted using the California Cooperative Oceanic

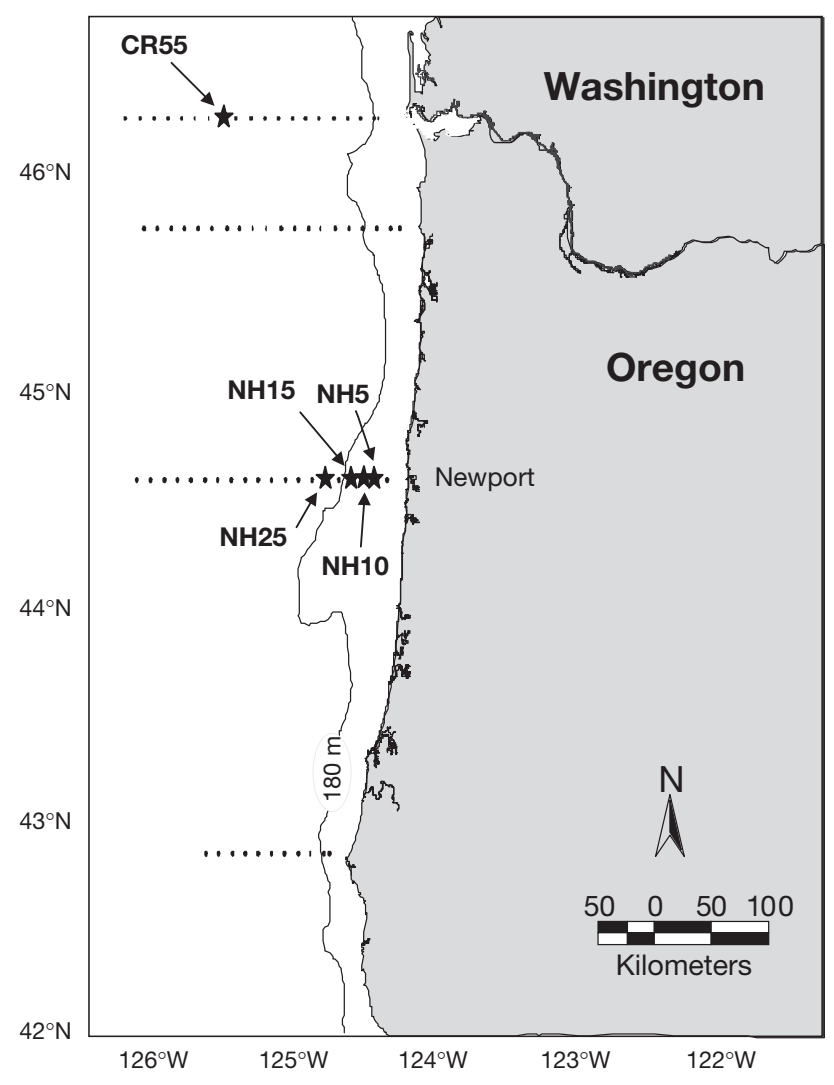

Fig. 1. Map of the study area showing Stns NH5, NH10, NH15, NH25 and CR55, where unusual species were collected, and the locations of transects occupied in 1997 that were sorted for copepods 
Fisheries Investigations (CalCOFI) protocol (Smith et al. 1985) with a $0.25 \mathrm{~m}$ diameter, $150 \mu \mathrm{m}$ mesh CalVET net. See Morgan et al. (2003) for complete methods.

For euphausiids and chaetognaths, the entire sample was usually examined, or (for 4 samples) a $1 / 4$ or $1 / 2$ split was examined because numbers of euphausiid furcilia of all genera exceeded 200. All individuals were enumerated by species and life history stage and total length (from the carapace margin behind the eye to tip of the telson for euphausiids) was measured. Density (number per $1000 \mathrm{~m}^{3}$ ) of animals was calculated, though for the more unusual animals, density estimates are based on collection of very few individuals so those densities are very rough estimates. For the euphausiids, most samples were not sorted for stages younger than furcilia, although in a few samples, calyptopis stages of Nyctiphanes simplex were identified (Table 1). Juvenile and adult densities are also probably underestimates because those stages are likely to have been below the sampling range of the nets or to have avoided the nets during the day when most samples were taken. Copepods were examined in subsamples, speciating whenever possible.

Table 1. Nyctiphanes simplex. Estimated densities from $1 / 2 \mathrm{~m}$ vertical net collections. Calyptopes were not identified in all samples; adult and juvenile densities are probably underestimated due to net avoidance during the daytime collections

\begin{tabular}{|c|c|c|c|c|c|}
\hline Stn & $\begin{array}{l}\text { Sampling } \\
\text { date } \\
(\mathrm{mo} / \mathrm{d} / \mathrm{yr})\end{array}$ & $\begin{array}{c}\text { Life } \\
\text { history } \\
\text { stage }\end{array}$ & $\begin{array}{c}\text { Volume } \\
\text { of water } \\
\text { filtered } \\
\left(\mathrm{m}^{3}\right)\end{array}$ & $\begin{array}{l}\text { No. in } \\
\text { sample }\end{array}$ & $\begin{array}{c}\text { Density } \\
\text { (no./ } \\
\left.1000 \mathrm{~m}^{3}\right)\end{array}$ \\
\hline \multirow[t]{15}{*}{ NH5 } & $12 / 12 / 97$ & Furcilia & 37.6 & 3 & 80 \\
\hline & 01/30/98 & Furcilia & 17.2 & 3 & 175 \\
\hline & 03/05/98 & Calyptopis & 16.2 & 34 & 2093 \\
\hline & 03/05/98 & Furcilia & 16.2 & 7 & 431 \\
\hline & 04/05/98 & Furcilia & 12.5 & 8 & 642 \\
\hline & 04/10/98 & Furcilia & 16.4 & 36 & 2194 \\
\hline & 04/21/98 & Furcilia & 24.4 & 4 & 164 \\
\hline & 05/27/98 & Furcilia & 16.1 & 1 & 62 \\
\hline & 06/02/98 & Calyptopis & 15.3 & 7 & 489 \\
\hline & 06/02/98 & Furcilia & 15.3 & 1 & 65 \\
\hline & 06/12/98 & Furcilia & 25.6 & 4 & 156 \\
\hline & 08/06/98 & Furcilia & 12.9 & 2 & 156 \\
\hline & 08/27/98 & Furcilia & 19.9 & 2 & 100 \\
\hline & 09/24/98 & Furcilia & 11.4 & 1 & 88 \\
\hline & $11 / 16 / 98$ & Furcilia & 18.9 & 1 & 53 \\
\hline \multirow[t]{10}{*}{ NH15 } & 01/30/98 & Furcilia & 26.2 & 4 & 153 \\
\hline & 02/02/98 & Adult & 42.1 & 3 & 71 \\
\hline & 02/02/98 & Calyptopis & 42.1 & 13 & 310 \\
\hline & 02/02/98 & Furcilia & 42.1 & 1 & 24 \\
\hline & 02/02/98 & Juvenile & 42.1 & 1 & 24 \\
\hline & 03/05/98 & Furcilia & 23.1 & 8 & 325 \\
\hline & 03/18/98 & Calyptopis & 24.2 & 96 & 3965 \\
\hline & 03/18/98 & Furcilia & 24.2 & 15 & 620 \\
\hline & 06/02/98 & Furcilia & 23.1 & 1 & 43 \\
\hline & $10 / 05 / 98$ & Adult & 23.3 & 1 & 43 \\
\hline
\end{tabular}

\section{RESULTS}

Larvae of Nyctiphanes simplex first appeared off the central Oregon coast in December 1997 and persisted through November 1998 (Fig. 2, Table 1). Between the first and last date of collection, $N$. simplex larvae were found in $>50 \%$ of all $1 / 2 \mathrm{~m}$ vertical net samples collected at the 9 and $28 \mathrm{~km}$ stations (Stns NH5 and NH15). Adult $N$. simplex were first collected in $1 \mathrm{~m}$ net samples in January 1998 and were found through November 1998 (Table 2). A female carrying a brood-sac was collected in January 1998. Since 1998, N. simplex have not been collected in the bi-weekly sampling that has continued to present, even during the weak 2002/2003 El Niño. Total length of females was $11.0 \pm 0.29 \mathrm{~mm}$ (mean $\pm 1 \mathrm{SE}$ ) not accounting for shrinkage due to preservation; males averaged $10.5 \pm 0.75 \mathrm{~mm}$.

Single specimens of Euphausia recurva Hansen, 1905 (one $10.6 \mathrm{~mm}$ male) and E. mutica Hansen, 1905 (1 adult, not measured), 2 species never before reported in coastal Oregon waters, were collected in $1 \mathrm{~m}$ net tows from Stn NH25 in January 1998 and April 1998 respectively. Estimated densities from those single collections of individuals were 8.3 E. recurva and 3.8 E. mutica per $1000 \mathrm{~m}^{3}$.

Two species of chaetognaths never before reported off Oregon were collected in $1 / 2 \mathrm{~m}$ net tows at Stn NH15: 2 specimens of Sagitta pseudoserratodentata Tokioka, 1939 were collected in March 1998 and 1 specimen of $S$. hexaptera D'orbigny, 1836 was collected in April 1998. Estimated densities from those collections were 82.6 S. pseudoserratodentata and 42.7 S. hexaptera per $1000 \mathrm{~m}^{3}$.

Several specimens of Centropages bradyi Wheeler, 1899, a warm-water copepod that is rare off Oregon, were collected $103 \mathrm{~km}$ off the Columbia River (Stn CR55, 46 $16.0^{\prime} \mathrm{N}, 125^{\circ} 25.2^{\prime} \mathrm{W}$, > $2000 \mathrm{~m}$ water depth) on 17 July 1997 . Density in that sample was estimated at 7.4 ind $\mathrm{m}^{-3}$. This is the most nearshore and northerly collection reported to date.

\section{DISCUSSION}

El Niño events result in onshore and poleward transport of water, a process that, during summer off coastal Oregon, leads to partial or total replacement of the typical boreal neritic species by species with offshore and/or subtropical affinities. During winter, when poleward transport is already the norm off Oregon, poleward transport may be anomalously strong during El Niños. The presence of Nyctiphanes simplex in our study area indicates that the water that appeared off Oregon may have originated from as far south as southern California, a distance of $>1200 \mathrm{~km}$ to the 


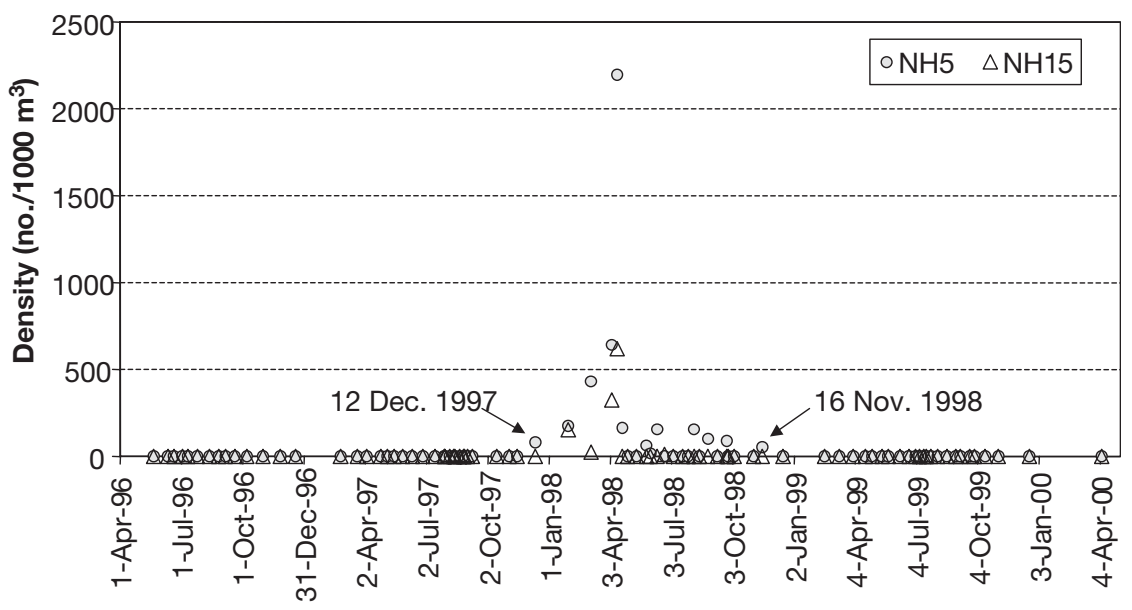

Fig. 2. Nyctiphanes simplex. Density (no. per $1000 \mathrm{~m}^{3}$ ) of furcilia collected by vertical hauls with a $1 / 2 \mathrm{~m}$ diameter, $202 \mu \mathrm{m}$ mesh plankton net from stations $9 \mathrm{~km}$ (Stn NH5) and 28 km (Stn NH15) off Newport, Oregon

Table 2. Nyctiphanes simplex. Estimated densities of juveniles and adults from $1 \mathrm{~m}$ net oblique tows

\begin{tabular}{|lcccrr|}
\hline $\begin{array}{l}\text { Sampling } \\
\text { date } \\
(\mathrm{mo} / \mathrm{d} / \mathrm{yr})\end{array}$ & Stn & $\begin{array}{c}\text { Life } \\
\text { history } \\
\text { stage }\end{array}$ & $\begin{array}{c}\text { Volume } \\
\text { of water } \\
\text { filtered } \\
\left(\mathrm{m}^{3}\right)\end{array}$ & $\begin{array}{c}\text { No. in } \\
\text { sample }\end{array}$ & $\begin{array}{c}\text { Density } \\
(\text { no./ } \\
\left.1000 \mathrm{~m}^{3}\right)\end{array}$ \\
\hline $1 / 30 / 98$ & NH15 & Female & 240.2 & 1 & 4 \\
$1 / 30 / 98$ & NH15 & Juvenile & 240.2 & 4 & 16 \\
$4 / 4 / 98$ & NH25 & Male & 259.6 & 1 & 4 \\
$4 / 5 / 98$ & NH10 & Juvenile & 270.9 & 126 & 466 \\
$4 / 5 / 98$ & NH10 & Male & 270.9 & 4 & 15 \\
$8 / 14 / 98$ & NH15 & Juvenile & 270.9 & 1 & 4 \\
$11 / 16 / 98$ & NH15 & Female & 267.3 & 64 & 410 \\
$11 / 16 / 98$ & NH15 & Male & 272.9 & 112 & 235 \\
$11 / 16 / 98$ & NH15 & Juvenile & 272.9 & 32 & 117 \\
\hline
\end{tabular}

south. Assuming that the average poleward flow anomalies of $13.7 \mathrm{~cm} \mathrm{~s}^{-1}$, which began in mid-August 1997 (Kosro 2002), applied to the entire California Current, then displacement of the animals from the northern end of their normal range $\left(34^{\circ} \mathrm{N}\right)$ to the central Oregon coast $\left(44.7^{\circ} \mathrm{N}\right)$ would require $3.3 \mathrm{mo}$. Thus, the appearance of $N$. simplex off the central Oregon coast in mid-December 1997 was only slightly later than would be predicted by northward water transport alone. Mackas \& Galbraith (2002), who sampled in October 1997, May, June, July, and October 1998, reported the presence of $N$. simplex in Queen Charlotte Sound, BC $\left(\sim 51^{\circ} \mathrm{N}\right)$ during June 1998 and off Vancouver Island in May and July 1998. Tanasichuk \& Cooper (2002) collected N. simplex off southern Vancouver Island in May-September 1998. Applying Kosro's velocity anomalies, $N$. simplex may have arrived off southern British Columbia (BC) by December 1998 though the temporal sampling resolution was not sufficient to resolve the timing of their arrival.
N. simplex was not present off BC in either October 1997 or October 1998 (Mackas \& Galbraith 2002). Given that $N$. simplex is strictly a southern and coastal/neritic resident (Brinton \& Townsend 2003), their presence off Oregon and $\mathrm{BC}$ indicates that northward, rather than onshore, movement of warm water was the mechanism that brought this species into the study area.

Nyctiphanes simplex has previously only been reported from Oregon waters during the strong 1982/1983 El Niño (Brodeur 1986), during which poleward transport was also anomalously high. Gutierrez-Gomez (2004), who examined samples collected off Newport, Oregon, during the weak 1969/1970 El Niño, did not find N. simplex, nor did we see that species in our samples collected during the weak 2002/2003 El Niño, for which transport estimates are not yet available. Abundance of $N$. simplex off southern California is strongly correlated to the phase of the Pacific Decadal Oscillation (PDO) (Brinton \& Townsend 2003); N. simplex primarily occurred off southern California in significant numbers during the warm 1977 to 1999 phase of the PDO, and was in low abundances during cool phases (1948 to 1976 and 1999 to present) except during El Niño events.

The collection of an ovigerous female and several calyptopes indicate that Nyctiphanes simplex spawned off of Oregon. Lavaniegos (1992) estimated the development time from hatch to Calyptopis III as $11.5 \mathrm{~d}$ at $14^{\circ} \mathrm{C}$. Temperatures where our samples were collected ranged from 9.5 to $13.0^{\circ} \mathrm{C}$ at $3 \mathrm{~m}$ depth, so development time would likely be as much as $1.5 \times$ longer than Lavaniegos's estimates (based on Ross 1981). Calyptopes collected during winter when poleward currents were strong were probably spawned south of Oregon, but those collected in June 1998 when alongshore currents were weakly equatorward (Kosro 2002) were probably spawned off Oregon.

Most of the other unusual species we collected are found offshore of the California Current, so could only arrive off Oregon through some onshore transport mechanism. Euphausia recurva and E. mutica are typically restricted to offshore Transition Zone waters (Brinton 1962, Brinton \& Townsend 2003) (Fig. 3), though Marinovic et al. (2002) reported E. mutica in Monterey Bay during the El Niño. Sagitta pseudoserratodentata resides in Pacific Central waters and offshore of California to $43^{\circ} \mathrm{N}$ (Bieri 1959, Alvariño 1965) (Fig. 3). We found all of these species in our samples during late winter/spring 1998. 


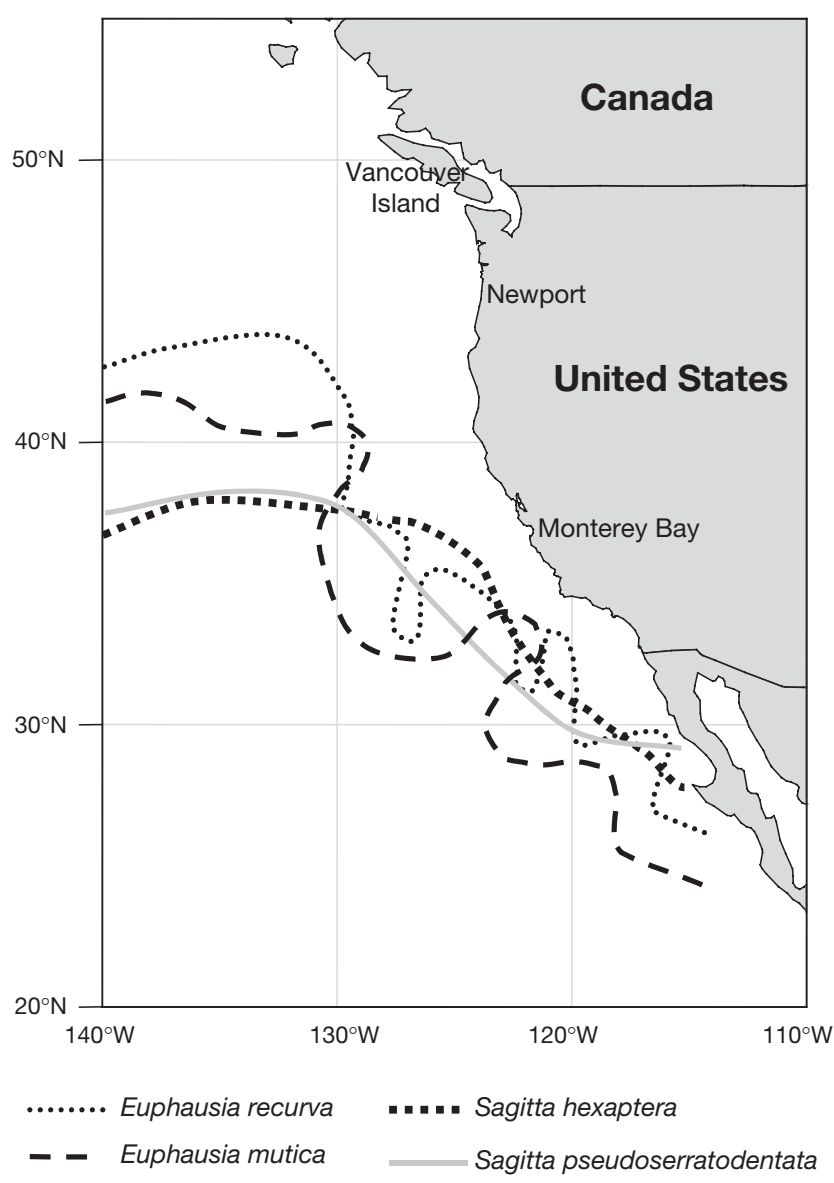

Fig. 3. Euphausia recurva, E. mutica, Sagitta hexaptera, and $S$. pseudoserratodentata. 'Normal' northern limit of the ranges of the euphausiids (adapted from Brinton 1962) and the chaetognaths (adapted from Bieri 1959)

Nearshore collections of Centropages bradyi have previously only been reported from waters south of Cape Mendocino, California $\left(\sim 40^{\circ} 23^{\prime} \mathrm{N}\right)$ (Bowman \& Johnson 1973). Peterson \& Anderson (1966) collected specimens from well offshore $(>300 \mathrm{~km})$ of Oregon at $\sim 45^{\circ} 42^{\prime} \mathrm{N}, 128^{\circ} \mathrm{W}$, which is $100 \mathrm{~km}$ south and $200 \mathrm{~km}$ west of our collection. Of the anomalous species reported here, $C$. bradyi was the first to be noted during the 1997/1998 El Niño: it was collected off the coast of Oregon in July 1997, after the first appearance of warm water, but before anomalously high sea levels. Because of its arrival early during the El Niño event, it seems likely that $C$. bradyi often resides in the warm water well offshore of the Oregon coast and only a slight onshore push of water brought it into the study area. We assume that wind-driven transport to the northeast by anomalously strong SW winds associated with storm events could transport the other species into our study area.

Most species previously reported in Oregon waters during El Niño events (Peterson et al. 2002, Keister \&
Peterson 2003, Peterson \& Keister 2003) are commonly found both to the south and offshore of Oregon, making it difficult to differentiate whether their occurrence during El Niño events result from onshore versus northward advection. Collections of zooplankton reported on here illustrate that both onshore and poleward advection are biologically important transport mechanisms during El Niño: Nyctiphanes simplex could only have been transported into our study area by northward movement of water whereas the other euphausiids, the chaetognaths, and the copepod probably required some northward, but primarily onshore, transport to bring them to the Oregon coast.

Acknowledgements. We thank P. M. Vance and L. Feinberg for assistance collecting and sorting euphausiids and J. Gomez-Guttierez for confirming the euphausiid identifications. Thank you also to R. Emmett, P. Bentley, and the captains and crew of the RV 'Sacajawea' and RV 'Sea Otter' for assistance with collection of the samples. Funds for this work were provided from the US GLOBEC Northeast Pacific Program (NOAA Grant NA860P0589 and NSF-SGER Grant OCE-9732386). This paper is contribution number 503 from the US GLOBEC program, jointly funded by the National Science Foundation and the National Oceanic and Atmospheric Administration.

\section{LITERATURE CITED}

Alvariño A (1965) Chaetognaths. In: Barnes H (ed) Oceanography and marine biology, Vol 3. Hafner Publishing, New York, p 115-194

Bieri R (1959) The distribution of the planktonic Chaetognatha in the Pacific and their relationship to the water masses. Limnol Oceanogr 4:1-28

Bowman T, Johnson M (1973) Distributional atlas of calanoid copepods in the California Current region, 1949 and 1950. CalCOFI Atlas No. 19, California Marine Research Committee, San Diego, CA

Brinton E (1962) The distribution of Pacific euphausiids. Bull Scripps Inst Oceanogr Univ Calif 8:51-269

Brinton E, Townsend AW (1980) Euphausiids in the Gulf of California - the 1957 cruises. CalCOFI (Calif Coop Ocean Fish Investig) Rep 21:211-236

Brinton E, Townsend AW (2003) Decadal variability in abundances of the dominant euphausiid species in southern sectors of the California Current. Deep-Sea Res II 50:2449-2472

Brodeur RD (1986) Northward displacement of the euphausiid Nyctiphanes simplex Hansen to Oregon and Washington waters following the El Niño event of 1982-83. J Crustac Biol 6:686-692

Gomez-Gutierrez J (2004) Comparative study of the population dynamics, secondary productivity, and reproductive ecology of the euphausiids Euphausia pacifica and Thysanoessa spinifera in the Oregon upwelling region. $\mathrm{PhD}$ thesis, Oregon State University, Corvallis, OR

Huyer A, Smith RL, Fleischbein J (2002) The coastal ocean off Oregon and Northern California during the 1997-8 El Niño. Prog Oceanogr 54:311-341

Keister JE, Peterson WT (2003) Zonal and seasonal variations in zooplankton community structure off the central Oregon coast, 1998-2000. Prog Oceanogr 57:341-361

Kosro PM (2002) A poleward jet and an equatorward under- 
current observed off Oregon and northern California during the 1997-98 El Niño. Prog Oceanogr 54:343-360

Lavaniegos BE (1992) Growth and larval development of $\mathrm{Nyc}$ tiphanes simplex in laboratory conditions. CalCOFI (Calif Coop Ocean Fish Investig) Rep 33:162-171

Lavaniegos BE (1995) Production of the euphausiid Nyctiphanes simplex in Vizcaino Bay, Western Baja California. J Crustac Biol 15:444-453

Mackas DL, Galbraith M (2002) Zooplankton community composition along the inner portion of Line P during the 1997-1998 El Niño event. Prog Oceanogr 54:423-437

Marinovic BB, Croll DA, Gong N, Benson SR, Chavez FP (2002) Effects of the 1997-1999 El Niño and La Niña events on zooplankton abundance and euphausiid community composition within the Monterey Bay coastal upwelling system. Prog Oceanogr 54:265-277

McPhaden MJ (1999) Genesis and evolution of the 1997-98 El Niño. Science 283:950-954

Morgan CA, Peterson WT, Emmett RL (2003) Onshoreoffshore variations in copepod community structure off the Oregon coast during the summer upwelling season. Mar Ecol Prog Ser 249:223-236

Pearcy W, Fisher J, Brodeur R, Johnson S (1985) Effects of the 1983 El Niño on coastal nekton off Oregon and Washington. In: Wooster WS (ed) El Niño North: Niño effects in the Eastern Subarctic Pacific Ocean, Vol WSG-WO 85-3. Washington Sea Grant Program, Seattle, WA, p 188-204

Pearcy WG (2002) Marine nekton off Oregon and the 1997-98 El Niño. Prog Oceanogr 54:399-403

Peterson WK, Anderson GC (1966) Net zooplankton data from

Editorial responsibility: Michael Landry (Contributing Editor), La Jolla, California, USA the Northeast Pacific Ocean: Columbia River Effluent Area, 1961, 1962. Technical Report No. 160. University of Washington, Seattle, WA

Peterson WT, Keister JE (2003) Interannual variability in copepod community composition at a coastal station in the northern California Current: a multivariate approach. Deep-Sea Res II 50:2499-2517

Peterson WT, Keister JE, Feinberg LR (2002) The effects of the 1997-1998 El Niño/La Niña events on hydrography and zooplankton off the central Oregon coast. Prog Oceanogr 54:381-398

Rojas LPL (2001) Estructura comunitaria do los eufausidos en la parte sur del sistema de la Corriente do California durante Octubre de 1997 (evento El Niño) y Octubre de 1999 (evento La Niña). MS thesis, Centro de Investigacion Cientifica y de Educacion Superior de Ensenada, Ensenada

Ross RM (1981) Laboratory culture and development of Euphausia pacifica. Limnol Oceanogr 26:235-246

Smith PE, Flerx W, Hewitt RP (1985) The CalCOFI vertical egg 2 (CalVET) net. In: Lasker (ed) An egg production method for estimating spawning biomass of pelagic fish: application to the northern anchovy (Engraulis mordax), Vol 36. NOAA Technical Report US Department of Commerce, National Marine Fisheries Service, Washington, DC, p 27-32

Strub PT, James C (2002) Altimeter-derived surface circulation in the large-scale NE Pacific Gyres. Part 2. 1997-1998 El Niño anomalies. Prog Oceanogr 53:185-214

Tanasichuk RW, Cooper C (2002) A northern extension of the range of the euphausiid Nyctiphanes simplex into Canadian water. J Crustac Biol 22:206-209

Submitted: April 1, 2004; Accepted: January 18, 2005 Proofs received from author(s): April 22, 2005 